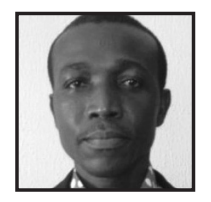

\title{
Discovering My Left Hand: Conducting Language Arts Research in Nigeria
}

\author{
Alexander Essien Timothy, University of Calabar
}

\begin{abstract}
Having been nurtured in the counting culture in Nigeria, my discovery of qualitative research methodology was as novel and subversive as using my left hand, which is considered a taboo in many Nigerian homes. This paper relates my initial attempt to deploy a qualitative methodology, especially art as a research tool, in investigating why Nigerian senior secondary school students and teachers hated Oral English. That study provided a canvas for the exhibition of art in my inquiry.
\end{abstract}

live and teach in Calabar, Cross River State, in the South-South geopolitical zone of Nigeria. Calabar was formerly in the defunct Biafra Republic. I lost one brother in the Nigerian civil war of 1967-1970. I lived in a refugee camp where, daily, children died, even my kid brother. My village lost more than three quarters of her citizens. After the civil war, some communities had no inhabitants. They had all died in the civil war. So, I was familiar with numbers and quantities. All my life, numbers and enumeration had dominated.

Nigeria was a British colony until 1960. Colonization bequeathed to Nigeria three key phenomena. First, it amalgamated culturally and linguistically diverse people into one geopolitical entity christened Nigeria after the adventurous River Niger that transverses several countries before washing into the Atlantic Ocean. Second, colonization gave us the English language, not only as the language of instruction, but also of communication in all sectors of the economy; a language of access to knowledge and opportunities, a language of governance and economic transactions, a language of social interaction 
and power brokerage, and as a language of unity. Above all, English has become a language for gaining global citizenship (British Council, 2011).

Third, colonization left Nigeria with a British-inherited system of education that extolled positivist thinking and quantitative reckonings. The complete rule of quantitative methodology (positivist measurement) is not only rooted in colonialism, but also in three decades of military rule. Thus, it was nurtured by a system that left room for neither alternative nor choice.

Fortunately, democracy and globalization have ushered in an increase in the free flow of information and the dissolution of intellectual borders. There is, therefore, a real threat to positivist hegemony. And my discovery of the left hand represents such a threat.

Currently, the resistance to post-positivist epistemologies, therefore, seem to arise, primarily, from ignorance, or more precisely, from unfamiliarity with qualitative methodologies and ethos. It is neither "politics" nor "PR" as Finlay (n. d.) would suggest. My experience and that of some of my colleagues who were initiated into this new way of inquiry is that we usually have an uphill task trying to convince some local editors that our work is indeed "empirical." Thus, the resistance is likely to wane as knowledge and practice of qualitative research increase.

\section{The Encounter}

I first encountered qualitative research in February 2013, soon after I was appointed a lecturer in one of the universities in Southeastern Nigeria. I had previously been a teacher of English at the secondary level for 24 years. The only research tools I knew and could use were the quantitative ones. When I discovered qualitative research through a Fulbright scholar from the United States of America who served in my university, I not only discovered a new research paradigm, but I also discovered myself and reclaimed my arts and those of my participants. I became subversive. I began to query the legitimacy of statistical dictatorship. A poem declared my insurgency:

\section{The Faceless Percentages}

Of the faceless percentages, the grotesque "half"s and the point twos and two thirds of the vanquished by AIDS, is a baby, my sister's only baby, that once sweetened their home 
but later broke their hearts and that sad home.

In that sterile statistic is my sister, whose daughter's bones now

refuse consolation for an avoidable grave,

my sister who now has a label, another christening

PLWHA, who has lost a name, a face, a home, a marriage

and her first joy and dearest grief.

In that barren number is my brother, my elder brother, tender, loving, gentle preacher

who died preaching the fear of HIV, afraid his parishioners would find out, colluding with a brother, that's me, afraid his wife would find out, too.

And a physician, true dear friend, afraid his colleagues would think he too belongs to the number.

Oh yes, my brother's daughter, years before he himself succumbed to AIDS and became just a digit.

Now she is a number in the valley of bones

Qualitative research taught me reflection. I never knew my thoughts could be data. I remember, one day, while sharing a thought with the Fulbright Scholar who introduced me to qualitative research, she asked, "Have you written it down?"

In perplexity, I asked, "Written what?"

“What you've just told me, of course!" A grin tugged the sides of her mouth.

"What...what for? Why? I said I was just thinking..." I stammered in confusion.

"It's your data. Your thoughts...when you ruminate and reflect on your actions and others' or on data you have collected, conversations you had, memories they trigger, write them down."

This was new. Before now, I had always been taught that data was what one got from others through surveys and interviews. Thoughts as data? Well, that was really strange. I knew that the researcher was expected to keep aloof from the research. Every intrusion of self was considered injurious to data collection and capable of contaminating the result. In my training, researchers made efforts to desensitize the research participants from even being aware that they were involved in a research study. The reliability and validity of findings would depend on how unobtrusive you were. 
What I was hearing now was that you have to tell your participants up front what your intentions are and even share with them your comments and your reflections about their responses. This demanded a new way of thinking as well as a new way of engaging and accounting. I found beauty in this research culture, in the openness and respect that would characterize the relationship between the researcher and the participant. The participant is no longer a mere research subject, but a partner who can share not only in the research process, but also in the product. Even the forms in which research may be conducted and reported are malleable enough to accommodate a wide aesthetic spectrum. I discovered that participants might respond not only by merely ticking some confined spaces in a survey, but also by writing prose or poetry or songs; they could talk or draw or take photographs, or even use sculpture (Deacon, 2000). This is science finding expression in art, and art basking in science. This is liberty.

\section{Left Hand as Taboo}

It is a taboo in all parts of Nigeria to offer your left hand to anyone, even your enemy. Children who are born left-handed embarrass their parents greatly. Parents go to great pains and put their children at greater pains to make their left-handed children right-handed. When libation is poured to the ancestors, it is done with the right hand, but when it is offered to the wicked ones, the left hand is used. The left hand is considered cursed. But why does the left hand fascinate me?

\section{Discovering My Left Hand}

Imagine

you were born in a community

where everyone is so right-handed

that whenever hand is mentioned,

one thinks only of the right hand.

Imagine

that one day someone shows you your left hand

and teaches you to use it.

If you embrace that knowledge, members of your community view you and your knowledge with suspicion, alarm and disdain.

What options would you have? 
You can jettison the troublesome left-handedness and revert to your familiar, accepted right-handedness; or you can ignore the cynicism, labour to be skillful in your newfound left-handedness and hope that your skill might eventually attract interest if not sympathy and acceptance.

\section{Deploying My Left Hand: A Study of Oral English Teaching in Nigeria}

This new understanding had to be tested. This new way of thinking had to be applied. So, I decided to deploy my left hand in a research concern I had planned to conduct in the familiar quantitative way. It was an examination of students' and teachers' attitudes towards Oral English.

Oral English is one of the components of The English Language Curriculum for Senior Secondary Schools published by the Nigerian Educational Research Development Council (NERDC). The components are:

(1) Vocabulary Development

(2) Oracy Skills (comprising Spoken English, and Listening for Comprehension)

(3) Literacy Skills (comprising Reading for Comprehension and Effective Study, and Writing for Effective Communication)

(4) English Grammatical Structures

The major national examination bodies (West African Examination Council [WAEC] and National Examination Council [NECO]), whose syllabuses inform the actual interpretation and teaching of the components, examine these components. Englishlanguage text publishers derive contents from the national curriculum and pattern their books to closely address the examinations.

Although Nigeria's English Language Curriculum proposes both productive and receptive skills, teachers and textbook writers gravitate towards examination requirements. A case in point is the Senior English Project for Senior Secondary Schools (Grant, Olagogke, Nnamonu, \& Jowitt, 2011), Book 3. It includes the following items under Listening and Speaking: 
symbols, word stress, debate, vowels /ə/, // /, /i: /; rhyme, listening to an argument, the vowel, stress in compound words, listening to main points, consonant clusters, pronouncing the letter a, listening to a play, sentence stress, emphatic or contrastive stress; intonation, dialogue, listening to a poem for paraphrase, etc.

However, in practice or implementation, speech is tactically eliminated. In the practice test section, there is no practice on intonation or any aspect of listening or speaking (Grant et al., 2011).

It is not surprising that since the examination bodies have shifted from the assessment of oral production and receptive skills to the test of the recognition of sound symbols, rhymed words, syllabic and emphatic stress, teachers would align their English lessons with what the examinations test.

The English Language examination is in three parts, called "papers." Paper 3 is a multiple-choice test called "Test of Orals" (Oracy Skills). It consists of 60 questions. The examination is purely multiple-choice and computer-based and is compulsory for admission into tertiary institutions in Nigeria. Oral English as tested by examination bodies in Nigeria is a test of consonants, consonant clusters, vowels, diphthongs, word rhymes, emphatic or contrastive stress, and syllabic stress. It is strictly a test of the grapheme, rather than the phonemes of the English language. It is a test of a textual appreciation of an oral phenomenon.

Although English is the official language in Nigeria and features prominently in all facets of life, students' performance in the English Language examinations has continued to be less than desirable. Olatunji (2012) writes of "the mass failure in English Language that has become endemic among Nigerian students at all levels of education" (p. 269). For example, in 2014, NECO reported that only 52\% of the candidates scored Credit (50-64 percent) and above in English Language. Since a credit in English Language is a prerequisite for admission into universities and other tertiary institutions, poor performance in English can thwart students' dreams of furthering their education (Osisanwo, 2005). Awonusi (2010) refers to "a calamitous failure rate in School Certificate English examination every year with the oral component playing a significant part" (p. 44). In other words, poor performance in English language is inseparable from the poor performance in Oral English. Mbah and Ayegba (2012) describe students' performance in Oral English as "very poor."

As one who has taught English language at the secondary school level for over 20 years and participated as an assistant examiner for one of the examination bodies 
in Nigeria, I could identify with "very poor" as a description of the general situation. However, the circumstances of my students were a little different.

To explain, let me start with a confession. I was not taught Oral English in secondary school (1976-1983). At the time, Oral English was separate from English Language and, therefore, optional. I further confess that although my first degree is in Education/ English, I was never taught Oral English as an undergraduate. Fortunately, when the West African Examination Council (WAEC) decided to make Oral English a component of the English Language examination, I was offered the opportunity to attend workshops for prospective examiners. Those were my first formal training sessions in Oral English, and they ignited in me a passion for Oral English-a passion not only to learn, but also to teach.

Many of my students shared my passion. They would come to me with their discoveries about how a particular word was pronounced differently from the way we regularly did, and I would check the dictionary and confirm that that was right. One of my students gave me a set of Professor Gimson's Oral English cassettes along with a companion book, which became our practice material during and after class. I organized debates and plays in the school and had many speech drills to prepare the students for the examination, which, at that time, was speech-based. We were actually using oral English, engaging with English speech in a variety of ways, and I witnessed my students' growth in competence and enthusiasm.

My next appointment was at a teacher training college where spoken English, both production and receptive skills, were taught and examined. These classes gave me added opportunity to do what I enjoyed doing and to witness the transformation of my students' speech. Besides, I had resources (audiotapes) that the students and other English Language teachers found most useful.

When I left the teacher training college and joined the services of a private secondary school three years later, the WAEC had stopped the Spoken English examination and introduced textual "oral" English. However, I continued to teach speech, actual production of oral English, while also teaching for the examination. By this time, my students sometimes considered the lessons in speech funny, and sometimes timewasting. Timewasting, because, I believe, they knew it was not what they were going to be tested on. But since I coordinated debate and drama in the school, often our debate and drama sessions became avenues for us to learn and use correct pronunciation, syllabic stress, and intonation. My students often did well on the examinations. I won the Board of Governors prize, which was given to teachers if more than 80 percent of their students achieved "Credit and above." 


\section{Looking at Poor Performance in Oral English}

Performance in English has continued to deteriorate in Nigeria. In 2013, the success rate at the West African Senior Schools Certificate Examination (WASSCE) dropped to $36.57 \%$, and $31.28 \%$ in 2014 (Ogundele, Olanipekun, \& Aina, 2014). One of the reasons suggested for the poor performance of students is lack of interest (Oyinloye \& Ajayi, 2011).

Since the WAEC Chief Examiners Report (2013) showed that students performed differently in the various components of English tested, I wanted to find out which components students liked and why they preferred those components. I thought such knowledge could help teachers to know how to make all components likeable, thereby improving students' performance. I obtained permission from the principal and teachers as well as the students' consent. Moreover, I assured them of anonymity.

I conducted my first interview with students in their final year in secondary school. Teachers were not originally part of the sample, but while interviewing the students, it became apparent that I needed to talk with the English Language teachers too.

\section{My First Question}

What aspect of English language do you like most?

I didn't know how to isolate and interview them one after the other. As soon as I attempted to recruit one, another volunteered and would call a friend. So I spoke with small groups of students, recording our dialogue on my cell phone. They shocked me. Instead of docilely responding to the question I asked, they said that I should ask them instead what aspect they disliked. Perhaps it was my inexperience, but I gave in to their request to talk about what aspect of English they hated the most. I was excited that qualitative research had given even my participants a voice. And when I asked what aspect of English they most disliked, almost unanimously, they said that they didn't like Oral English.

\section{Why?}

Oral English is often taught late-usually in the senior secondary school. It is an examination requirement mainly at the senior secondary school level. One of the participants, Vicky, said she was not taught Oral English until she was in SS2 (equivalent to Grade 11). Thus, after about 10 years of formal education, students are introduced to "another English." 
In addition, the discrepancy between the English alphabet and phonetic symbols baffles them. After about six years of primary education and possibly three years of lower secondary, students are confronted by a new "alphabet," where /j/ is not the sound for jell, but for yell. For instance, Marble complains, "The phonetic symbols are different from the familiar letters a, e, i, o, u." Another student, Adie, is very direct: "It's annoying because most especially the vowel sounds are not even English Language."

I don't like oral English;

It's really annoying -

too much of pronunciation;

all that uuuu,

all that ahhhh,

it's really noisy

(Found poem from Adie's interview, March 2013)

Mr. Ngasse, teacher of English at Senior Secondary Three, tried to explain why students may find oral English uninteresting and difficult: “...perhaps the exposure they had to oral English was limited ... because their teachers at the lower secondary were not very competent in teaching that aspect of the language." Another teacher, Tessy, concurred, "For Oral English, students in junior class are not taught how to pronounce words." In essence, the students see Oral English as a new English.

\section{New English}

This new English is no fun

which teacher says is pronounced fan.

But soon becomes bat

(only in the class).

And when teacher swears

that ewe is now you,

we wink at one another

knowing that this too shall pass.

Just let the bell ring

and mother shall be moda

and father, fada.

Even teacher will agree.

Just let the bell ring! 
The participants often find oral English mysterious. From my interview with Val and Wenda:

Val: $\quad$ Then the part of English I HATE is em...I don't really like is syllabification or something. Is there something like that?

Me: $\quad$ Syllabic stress?

Val: $\quad$ Yeah, yeah, syllabic pattern, Oh my gosh! Yeah, I don't really like that 'cause I'm not really good at it. I don't really understand how it goes, how, what you have to do, yeah, I don't really like that...

Wenda: I really have a problem with English. When I speak the English, it's easier than when you see so many vowel sounds that are different from the vowels themselves a, e, i, o, u, and then you're sort of confused how to pronounce it...

Me: Is it that the symbols are different from the letters?

Wenda: Yes, the symbols that are used to represent it and sometimes like you have the inverted e and you're not sure how you're supposed to pronounce it. And at times even as much as you cram, when you get to exam hall, you're thinking, "how is this pronounced?"

Would this conversation have been possible if I had given the students a survey? Could there have been a dialogue, a narrative, and a story? Coming from a story-telling tradition, where even my 17-year-old daughter still craves folktales about Tortoise, I find some recreation (I'm afraid this sounds very unscholarly) in the conversations my participants and I have. My participants also seem to enjoy this form of research, perhaps for its novelty. For the first time, my participants become human. They are recognized, their opinions respected and even sought, and their perspectives valued. These relational qualities are much more in tune with Nigerian ways of being in community.

\section{School-Only Pedagogy}

Language education that centres on examination only is likely to create a gulf between what happens in school and in real life. What children learn in class is often left behind. The language they encounter outside the class and at home is usually different from the one they are taught in class. Even students' out-of-class speech indicates that there is a dissonance between what they learn in class and what they experience outside the class-even from their teachers of English. Sam, one of the respondents, confesses: 
I was not taught earlier on in primary and secondary school. We only speak English in the school arena. Once we leave the environ, we go back to our Nigerian language. We don't speak English regularly. The teacher didn't show us that the English was very important. We only studied English because it is necessary in school. Even when our parents are speaking with us, they speak in Igbo. Even our teachers when they see you outside the class they don't even make any attempt to speak English with you; they speak the local language with you.

From such voices, I constructed the following poem:

\section{Another English}

Here we go again!

I thought I had mastered my abc

Teacher is perplexed

so am I

Who wouldn't be?

Seeing our faces riddled with confusion

creasing our teacher's brows

aging him in his youth?

It takes just a class frustrated

by the letter e,

now prostrate on its back

and the letter j not spelling jet but yet, and teacher screams, tongue in cheek, that star is not star but starrrr

And come is spelt with an inverted v.

Oh perplexity cannot spell difficulty!

\section{Killing the Dance}

One reason that participants offered for their dislike of oral English was that it was not, after all, about speaking, but about writing. And this has to do with the nature of the Oral English examination. Baturay, Sancar Tokmak, Dogusoy, and Daloglu (2011) maintain that:

Oral assessment is often carried out to look for students' ability to produce words and phrases by evaluating students' fulfilment of a variety of tasks such as asking and answering questions about themselves, doing role-plays, making up mini dialogues... or talking about given themes.... (p. 60) 
Although this is what I had enjoyed doing with my own students, this is not the usual case in Nigeria. Awonusi (2010) very aptly describes "the replacement of a production test with a perception test" and a test of "practical pronunciation through writing, an odd device of testing a primary communication process through a secondary communication process" (p. 44). I call this phenomenon "Killing the dance":

\section{Killing the Dance}

The drums thump

fiery rhythms course through my blood

calling Iwali,* Queen Dancer of Bekwarra!

supple maiden... gentle ripple like the waves...

Drums gyrate in nimble timbre, beckon...

dexterous cadences coax the limbs, implore...

Charmed, my feet quiver with the tremor of the drums

and sweep to the arena

as custodians of the drums announce:

There shall be no dance.

* Iwali is an institution in Bekwarra in Cross River State, Nigeria, where a virgin is secluded and trained in dancing and culinary arts, kept trim and beautiful for seven years. She is called Iwali the queen dancer. The crowning moment of her seclusion and preparation is the dance. Her parents, guardians, and tutors look forward to the day she will exhibit her beauty and her carefully rehearsed dance steps, which not only entertains, but also ritually cleanses. It's suicidal for the custodians of the drums to say, "there shall be no dance!" In a similar context, a popular Juju musician from western Nigeria sings in Yoruba, "Igba $n$ ba jo lonilu gbelu," "Just as I'm about to start dancing, the rhythm is withdrawn" (Ebenezer Obey'). Such sentiments convey, I believe, what the examination bodies do to the students, who learn oral English, but have no opportunity to actually use it in the exam. 


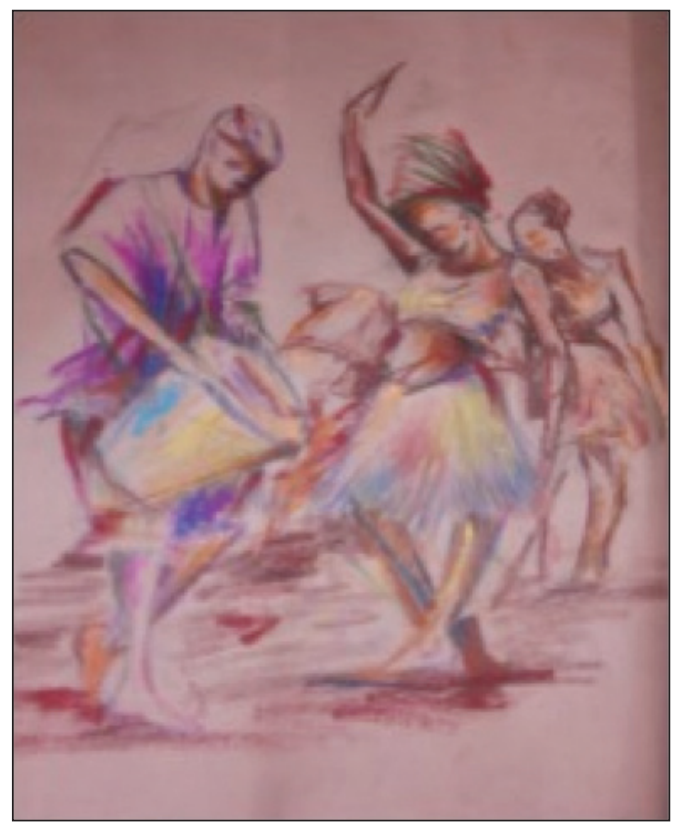

Fig. 1: Killing the dance ${ }^{2}$

\section{What's the Use?}

A very important reason why participants had an aversion to oral English was its seeming lack of utility. To most of the respondents, Oral English didn't seem to have any practical value beyond the English exam. Itham and Mabel wished they were taught public speaking instead. According to Mabel, public speaking "is more useful to us than Oral English which is only for exam." Students, it would appear, are unable to see any link between the Oral English component of English Language and real-life communication.

Of what use is the diphthong

When it makes you lose your tongue?

Who cares for weird vowels

that simply turn your bowels

or phony shorthand

that can't really stand

when the tyres meet the road

and you carry the load

of remembering which

consonants spells which 
or which syllable bears the stress

and which you need suppress?

\section{Some Love It So}

Some students actually love Oral English. One of the participants, Reda, said Oral English would help her pronounce words correctly. Iso sees Oral English as being useful in learning the spelling of words and in using the dictionary. Of all my students, Baba was the most passionate about Oral English. For him, English, particularly Oral English, was very useful for self-discovery, social interaction, and metacognition. The following found poem is from Baba's interview transcript:

\section{English I love}

Hah! (Exhales - in relief (?)) to me English is for me

English is English

is an interesting that I would really like to go into it, that I'll really like to scrutinise more.

'cause I believe

it's really interesting - the English subject,

the English language,

oral English,

everything about English;

I really love it,

I really ...

English makes me love language,

I really love it.

When you go deep into English

like to have more idea about others

when you interpret it

...translate it with your own language,

you... you...., you have more...

you have more ideas...

you have more...

you have more...

You have more, you 


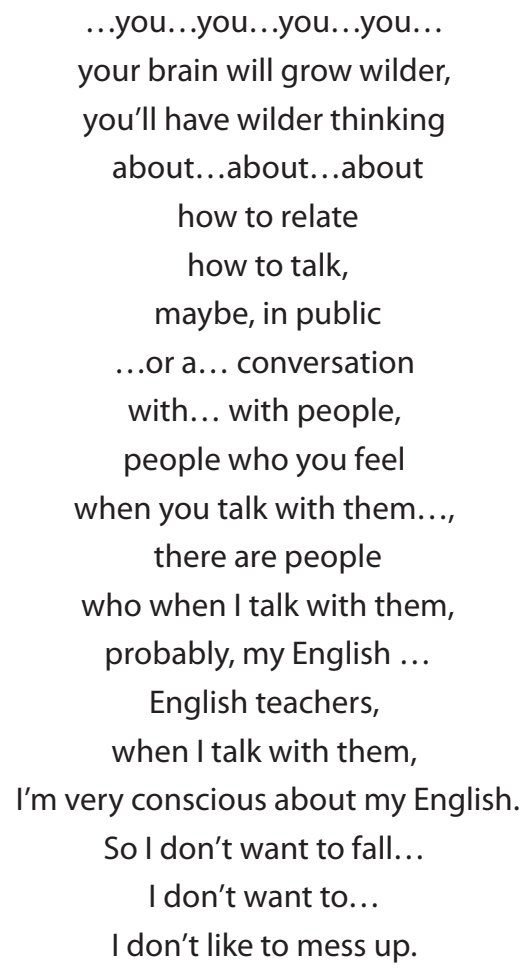

It seems Baba is excited, not by the way oral English it is taught and examined, but by the ways he can use it in conversation and in thought.

\section{Teachers' Nightmare Too}

When I found out that the components students hated was Oral English, I needed to find out teachers' attitudes towards the different components of English. My reasoning was that if teachers dislike any topic or aspect of the English language syllabus for whatever reason, they may avoid teaching it or teach it without enthusiasm. As a corollary, students may not develop high interest in any topic or component of English that the teacher approaches with apathy; and, lacking interest, their performance is likely to be poor. Attitudes to a subject can determine the quality of teachers' teaching (Olatunji, 2012; Lope \& Bagheri, 2011). Therefore, I decided to also find out from teachers the aspects of English they didn't like.

At this point, I must admit that with quantitative research I wouldn't have thought about doing a follow-up in the same study. Such iteration now seems the most natural thing to do. Thus, I think qualitative research works like an oil rig. 


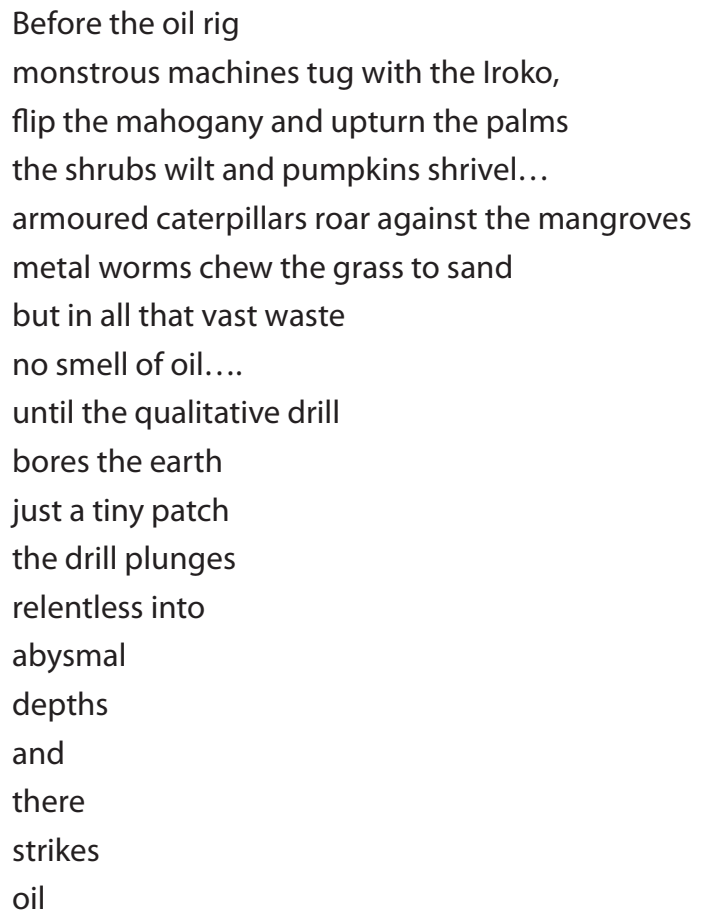

Quantitative research clears the bush, while qualitative research probes the depths.

Initially, when I asked the teachers which aspects of English they didn't like, unanimously, they said, "none." But when, as a follow-up, I later sent a text message to ask them which aspects they thought teachers of English generally found most challenging to teach, each of them texted back, "Oral English." Their earlier response is understandable because it is not advantageous for teachers to admit a weakness to someone else. As one who had taught English language in secondary schools for about two decades, I cannot feign ignorance of the phobia some English teachers in Nigeria have when it comes to teaching Oral English. The following poem captures such phobia:

\section{Teacher in a Well}

Our teacher dreads our class.

This we know.

Once he crosses our threshold the smile is erased from his face:

English is a serious business, 
so we throw him a lifeline,

Goooood morrrrning Ser!

He writes on the board

the new alphabet;

We adjust in our seats.

Aluta continua...

He prays we won't ask him a question;

We pray, too.

But when we would know why cough

wouldn't rhyme with rough

and though doesn't agree with tough

Teacher finds himself in a well

Well...well...well...em...well,

do you understand?

We exchange glances.

Pained by our addled gapes,

teacher prays for the bell...

we pray, too.

Well...you see....

Well ...in fact...

Well, we understand

that the English of this class is different

different from the English of our playground

different from the English in the church

different from the English at home!

THAT we understand,

though we don't understand WHY.

In benign conspiracy,

we reply, jess Serr!

\section{The Elixir: Let's Dance}

It is apparent that Oral English in Nigeria is bereft of the speech component. The examination organizations do not test the speech component of Oral English, so teachers are likely to align their teaching with examination requirements. To reverse the trend, the West African Examination Council (WAEC) should reintroduce the true oral spoken English examination. Don't cease the beat when the dancers are ready to dance. 
While examination bodies may hesitate to reintroduce speech in Oral English, teachers can still expose students early on to speech in news broadcasts, oral reading, debate, drama, films, songs, poetry, and so forth. The best driving training is not limited to a four-year course on driving theory. No pilot flies a plane just by reading about how to fly a plane. Similarly, in speech, we learn to speak by speaking. The way forward is to teach speech.

\section{Quantitative Interference in Qualitative Research: A Personal Reflection}

As a new practitioner of qualitative research, my quantitative roots still intrude into my research. I was born into a world ruled by numbers. My mother wasn't very happy when I was born male. She had had two stillbirths, all girls before my elder brother came. She expected the next to be a girl (She says they grow faster, mature early, and are stronger at carrying younger siblings). I couldn't start school as early as I would have wished. My hands would not touch my ears across my rather big head.

When my hands refused to grow long enough to touch my ears, my mother played the number card. She told the headmaster that I could count 1 to 10 -and in English too!

"Let's hear him," The headmaster's eyes lit.

"One..." I began the counting that has refused to end.

Since then, counting and quantifying have dominated my life and academics. I didn't have an alternative until after 49 years of counting when a Fulbright scholar in my university revealed qualitative research. Initially, it seemed preposterous. How could one engage in an empirical research without counting? Nevertheless, with excitement for this new possibility of freedom from numbers, I ran out to gather qualitative data. But the first question that struck me was: How many?

I noticed that after transcribing the interviews, I would query, "Is this sample enough?" I'd count the number of persons I had interviewed. Not enough! I'd fly out to seek more participants to interview. Then, when I was overwhelmed by the number, I'd just dump everything and backslide to a counting regime. I'd then design or adapt a quantifiable questionnaire and hire assistants to help administer it. I would code the 
values into numbers; feed them into my computers. Then SPSS (Statistical Package for Social Sciences). Voilà! I have results, numbers, tables, charts, and graphs!

I seem unable to resist the quantitative "devil" that whispers a familiar path. It feeds on my every hesitation on the qualitative path. It seduces me into the wellworn quantitative footpaths and throws me into the comfort of the quantitative embrace. I find myself counting. I count the number of keywords. I tabulate and find the percentage of occurrence of themes. I count the types of verbs. I count the number of metaphors used by a participant. All the while, a voice mocks, "Still counting, Son!"

Then the voice taunts, “Give it up, man. You're born to count. Don't delude yourself. Nobody wants to know that students performed excellently in English. They want to know how many students scored 80 and above!"

Moreover, my ridiculously small sample can't stand the count of my faculty assessment panel. Even they seek a number. How many publications? How many local journals? How many international? How many workshops? How many years since your last promotion? Local and regional journals sneer at the "non-generalizability" of my findings on account of the sample size. Everyone seeks a number. In my university, typical of universities in West Africa, the association of quantification with empirical research effectively hampers the qualitative dance.

Is QR an alternative or a deviant form of research? Is it a protest research model, a rebellion against statistical tyranny? Am I attracted to the deviant element? Is it the sweet lure of rebellion or the intoxicating breath of democracy? (Journal, 16/6/2014)

With respect to language arts in particular, qualitative inquiry provides the space to leap and spin, the space to crouch and wriggle, the space to hop and bounce, the space to merge with the drums and dissolve in the dance. It offers an effective tool to peel off layers of meaning and allows access to empirical depths that may be inaccessible by quantitative methods alone. It allows for a research experience that includes communal engagement, a traditional Nigerian value, in which both teachers and students participate. In the post-colonial era, as we continue to experiment with democracy in Nigeria and strive to create an educational system that works towards that end, qualitative research beckons for attention, seeking more intellectual space and broader use. Let the dance continue. 


\section{Notes}

\section{Please see: https://en.wikipedia.org/wiki/Ebenezer_Obey}

2. Ademola Francis Sanda provided the sketch that appears in Figure 1. Ademola is a junior colleague who is also my dear friend. He was excited to see me use poetry in reporting my research, and when I explained to him the dance analogy, he told me about the Yoruba musician, Ebenezer Obey. He gave me the Yoruba lyric and translated the meaning in English. Then I discussed with him that I'd love a drawing of a dance scene showing drummers and dancers. I picked up a pen and gave him a quick sketch of what I wanted. He understood immediately. In less than an hour, with his pencil and crayons, he produced the piece. Using my cell phone, I took photographs of the dancers, the drummer, and the entire piece.

\section{References}

Awonusi, S. (2010). Good spoken English and national development: Sociophonology in the service of man. Inaugural Lecture at the University of Lagos.

Baturay, M. H., Tokmak, H. S., Dogusoy, B., \& Daloglu A. (2011). The impact of task type on oral performance of English Language preparatory school students. Hacettepe Üniversitesi Eğitim Fakültesi Dergisi (H. U. Journal of Education), 41, 60-69.

British Council. (2011). British Council partners with HSBC in Indonesia to provide teacher training. Retrieved from http://www. britishcouncil.org/accessenglish-news-partners-with-hsbc-indonesia-provide-teacher -training.htm.

Deacon, S. A. (2000). Creativity within qualitative research on families: New ideas for old methods. The Qualitative Report, 4(3,4). Retrieved from http//www.nova.edu/ssss/QR/QR4-3/ deacon.html

Finlay, L. (n.d.). 'Rigour', 'ethical integrity' or 'artistry'? Reflexively reviewing criteria for evaluating qualitative research. Retrieved from www.lindafinlay.co.uk/BJOT_evaluating_research_new.doc.
Grant, N., Olagogke, D. O., Nnamonu, S., \& Jowitt, D. (2011). Senior English project for senior secondary schools. England: Pearson Education Ltd.

Lope Pihie, Z.A., \& Bagheri, A. (2011). Are teachers qualified to teach entrepreneurship? Analysis of entrepreneurial attitude and self-efficacy. Journal of Applied Sciences, 11, 3308-3314.

Mbah, E. E., \& Ayegba, M. (2012). Effect of peer correction on students' performance in Oral English. International Journal of Educational Science and Research (IJESR), 2(3), 45-52.

Ogundele, G. A., Olanipekun, S. S., \& Aina, J. K. (2014). Causes of poor performance in West African School Certificate Examination (WASCE) in Nigeria. Scholars Journal of Arts, Humanities and Social Sciences, 2(5B), 670-676. Retrieved from http://saspjournals. com/sjahss

Olatunji, S. O. (2012). English language teachers' attitudes to the promotion of the standard Nigerian English: A survey from a Nigerian city. African Research Review, An International Multidisciplinary Journal, Ethiopia, 6(3), Serial No. 26, doi:http://dx.doi.org/10.4314/afrrev. v6i3.20 
Osisanwo, W. (2005). The English language in Nigeria: A blessing or a cog in the wheel of progress. Special Lecture Series 01. Ondo: Adeyemi College of Education.

Oyinloye. G. O., \& Ajayi, B. B. (2011). Investigating technical college students' achievement in speech work in English Language. European Journal of Educational Studies, 3(1), 75-83.
West African Examination Council. (2013). Chief Examiners' Report. Lagos: WAEC.

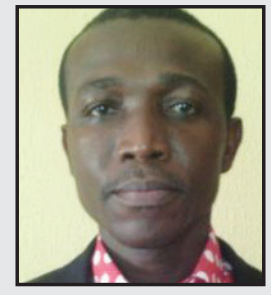

Alexander Essien Timothy teaches curriculum and language arts courses in the University of Calabar. He taught English and Literature-in-English in secondary schools for some 20 years before joining the university. He holds a PhD in Curriculum Studies with a specialization in language arts. He is interested in inclusive education, qualitative research, languagelearning technologies, reading education, television/Internet utilization in education, and differentiated instruction. 